\title{
The Image of China and Russia in the US Press During the Pandemic
}

\begin{abstract}
The United States press negatively portrays both Russia and China. During the current pandemic the image of these authoritarian states has become even more negative. The coronavirus situation works as interaction effects when more radical attitudes are reflected in the internet messengers and internet media. Previous media topics of US criticism have given the way to a dominant topic - the Chinese responsibility for a virus. Any success story coming either from China or Russia is doubted or silenced. No positive news can be found in the authoritarian political system. The data based on New York Times publications are used for the content analysis of the image of Russia and China.
\end{abstract}

Key words: image of China, image of Russia, Pew Research Center, Survey, Public Opinion, bias, the US Republican Party, the US Democratic Party

$\mathbf{T}$ he current pandemic of coronavirus has affected all countries in the world. The leap year 2020 has literally become a nightmare for many countries in the world. In the current conditions of rising numbers of the infected, finding a cure for a disease, preventing contagion, solving multiple problems international governments are expected to unite their forces, find better ways of prevention, and support each other in the struggle against the common enemy. Governments constantly monitor the situation and carefully observe efforts of other states since the success of implemented measures greatly depends on international neighbors and economic partners. Yet it is difficult to find omnipotent examples of international cooperation. Negativity in mutual perceptions and images tends to increase. Two large powers - Russia and China - have been critically perceived by many western countries. During the coronavirus pandemic, the level of negative perceptions of these countries increased even more. What can explain the current negative portrayal of Russia and China in the US media? Why cannot be at least some form of compromise and cooperation between Washington and Moscow/Beijing?

In order to answer the research question, the article proceeds with the examination of a negative image of Russia and China. Mass media and rational theories are applied to the explanation of the contemporary reality of bilateral relations in the United States and the importance of media in determining political preferences of the US citizens. Political goals of the US elites are taken into consideration. The elite media control is also analyzed. The content analysis method is employed in this study focusing on the main topics in the US news coverage.

The main theoretical framework of the article is based on the mass media studies. There have been many studies of mass opinion formation (Downs, 1957; Sniderman et al., 1991; Zaller, 1992). Downs (1957) notes that the average citizens in the United States is not expected to follow all the news. Information costs are high for ordinary citizens. Therefore, they need to rely on experts to make a decision in many matters (Downs, 1957). Zaller (1992) also emphasizes that the US forms its opinion based on 
the shortcuts given in the media. The information is shaped, framed and determined by elite groups (political parties, experts, university professors, journalists, interest groups, leaders of different economic, social, religious organizations). The news are selected for the general population who have little knowledge and political awareness. Therefore, the public opinions depend on this exposure of information. Receiving messages from elite determines the answer to any survey (Zaller, 1992). The average ignorance of the overwhelming majority of the US population in political matters implies the importance of cues and shortcuts received from the elites (Downs, 1957; Sniderman et al., 1991). There is a small group of individuals who are able to process the media news coverage and reject messages which are not consistent with their beliefs (Zaller, 1992), The elite messaging relies on all information tools. Old traditional news (TV channels, newspapers) and digital media are equally used and employed by elite groups.

What can be learnt about a coronavirus pandemic at the current time? There is much information of the constant updates coming from Johns Hopkins Coronavirus Resource Center, World Meters websites and many other international and national sources. National and local news constantly remind citizens of the current pandemic situation. The research work is not supposed to repeat this information that is easily available for general public. The main difficulty for the real research work projects is a relatively short time frame. The United States and many other western countries in the world were affected in FebruaryMarch providing few months for the analysis. The pace of changes is very rapid. Every day there is some shocking news coming from different countries. In this situation, the research work does not need to reflect journalistic coverage of the main events.

In addition, in the Political Science research relies on the data that are assembled, classified and published. Acquiring large data sets requires extensive work of government statistics offices which takes at least a year to collect information, then organize and publish the results. When we look at the entry of many variables at a certain point in History, example 2019, we can observe the situation of 2017-2018. That is why the method of employing a lagged variable is used in Political Science research. The impact of the factor can be expected the following year. The only way is to examine the content of the US news and determine main important features and characteristics.

In this work, the image of the modern People's Republic of China in the printed US media has been taken as an object. A high degree of monopolization in the US news agencies is another essential feature of the American media. The US elites highly control this field. A majority of media outlets caters to political groups (Republicans or Democrats). In the US, there have been a prevalence of eleven sources of news distribution. This list includes three newspapers: The New York Times, The Washington Post, The Walt Street Journal.

Another important aspect is that the United States as a global hegemon and great power has a significant impact on other countries and the world community as a whole. However, the key point in this scientific work is the negative nature of propaganda regarding China, although China has been the most important trading US partner. In this regard, it is necessary to analyze the content of the US publications to determine the main topics making up China's image. The main publications come from the New York Times, The Washington Post, Los Angeles Times, The Seattle Times, San Francisco Chronicle, USA Today, The Wall Street Journal. 
The image of China has been reflected in numerous US publications, from the daily print newspapers to online news sites. When considering the sphere of print media in the United States, one can distinguish a number of the most popular and popular publications: USA Today, The Wall Street Journal and The New York Times. But the New York times was the main focus. This work is based on data obtained from the third most popular newspaper, The New York Times. This choice is due to several reasons. Firstly, the New York Times provides archival information classified by topics and years, thereby ensuring a reliable and available data flow.

Secondly, the fact that the owner of The New York Times Company is Arthur Oaks Sulzberger Jr., who is a member of a private American organization in the field of international relations - the Council on Foreign Relations, is an important figure in the US media control.

The methodology is the content analysis of articles that was carried out in the time frame from January 1, 2000 to April 1, 2020 using a specific sample of words. Overall, 160,159 articles have been analyzed for the following marker words: power, strength, greatness, rivalry, army, Taiwan, Tiananmen, Tibet, Lama, human rights, protest, corruption, boom, military, ecology, threat, discrimination, racism, aggression, freedom, emissions, growth, Xinjiang, Hong Kong, virus. These are the main topics reflecting most widespread western key words about China. The selection of articles consisted of the presence of the words China or Chinese in the text. It is also important to point out that for a wider scope, when searching for words, various forms were used that express different grammatical meanings, such as ecology, ecological, ecologic and so on.

The main results give the most important words. Such key words as Taiwan, army, power and growth are top topics of the western media throughout several yeas (20002007). Only in 2008 did new themes (protest and Tiber) enter this most frequent topic list. It was explained by the protest movement and conflicts in the Tiber region. The western coverage provided support to the ethnic minority protests and actions. The years 2009-2013 came back to the previous top works (Taiwan, army, power and growth). Another change occurred in 2014, the year of protests in Hong Kong. In particular, almost all news regarding this topic covered events in Hong Kong. From September 26 to December 15, 2014, a series of sit-down street protests took place there, often called the "Umbrella Revolution". The dissatisfaction of Hong Kong citizens was caused by the intervention of Beijing in the Hong Kong election process, the protesters demanded transparent suffrage. Since these protests, China's Internet space has been heavily censored, and the popular YouTube site has also been blocked, since protest videos were posted there. After the return to the old dominant topics in the following years (2015-2018), the year 2019 returned the protest focus of the US publications. The struggle in Hong Kong and the extradition law dominated the western news coverage. The year 2020 gave prevalence to the virus coverage (analyzed until the middle of May) with the highest number of articles - 4298. In comparison, the second largest topic (threat coming from China) had only 244 mentions in the search engines.

In order to determine the impact of the negative portrayal of China, the results of Pew Research Center surveys are necessary to examine. The results of the negative coverage lead to unfavorable views of the US public following the studies of mass media researchers. 
Figure 1. Negative views of China in the US (Pew Research Center)

Negative views of China continue to grow in U.S.

$\%$ who say they Have a_Opinion of China

$100 \%$

66

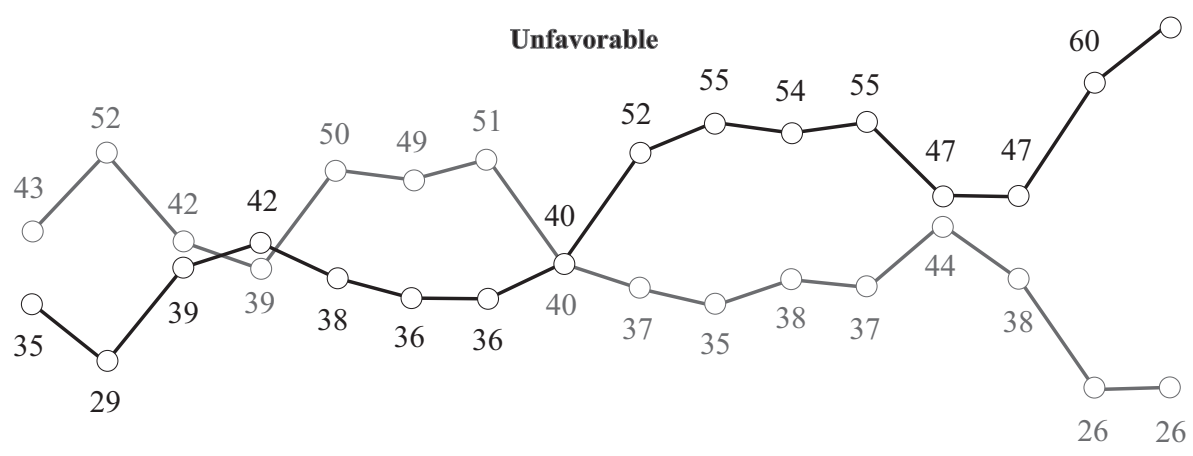

Favorable

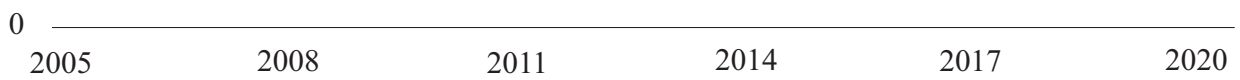

Source: Pew Research Center Survey Results (Devlin et al., 2020).

Based on Figure 1, the negative attitude of the United States public has been growing since 2017 - the first year of a new White House administration of Donald Trump. In $2017,47 \%$ of the US population had an unfavorable opinion of China, dramatically increasing to $60 \%$ in 2019 and $66 \%$ as of March 2020 which was the highest negative record. Positive attitudes towards China are shared only by $26 \%$ of the US respondents. President Donald Trump's emphasis on tariffs has led to a trade war between China and the US. This conflict had a great impact on the selection of the news about China. Interestingly, in the first term of Barack Obama's presidency (2009-2013) there was a better perception of China in the US with a higher percentage of the US population having a favorable opinion of this country (around 50\% in 2009-2011) (Devlin et al., 2020).

Based on the data from the Pew Research survey conducted on March 3-29, 2020 one thousand US respondents negatively viewed the Chinese leader (Xi), China's power and influence which are perceived as a threat to the US. It was not only Trump's negative statements and media bias causing these unfavorable US reviews. The economic variables - losses of the US industries and growing trade deficit played a large role in these negative perceptions (Devlin et al, 2020). In addition, the public cite other topics brought by the media - environmental problems and China's bad human rights record.

The negative attitude to China is shaped and affected by partisan preferences of the US respondents. Figure 2 shows the division between Republican and Democrat supporters. Throughout this time frame (2005-2020), the Republicans are 5-10 percentage points higher than the Democrats in having an unfavorable opinion about China. The Republicans tend to be worried about China becoming a global economic power and 
Figure 2. The Views of China. Comparison of Republican and Democrat supporters Republicans consistently more negative than Democrats toward China

$\%$ who say they have a unfavorable opinion of China

$100 \%$

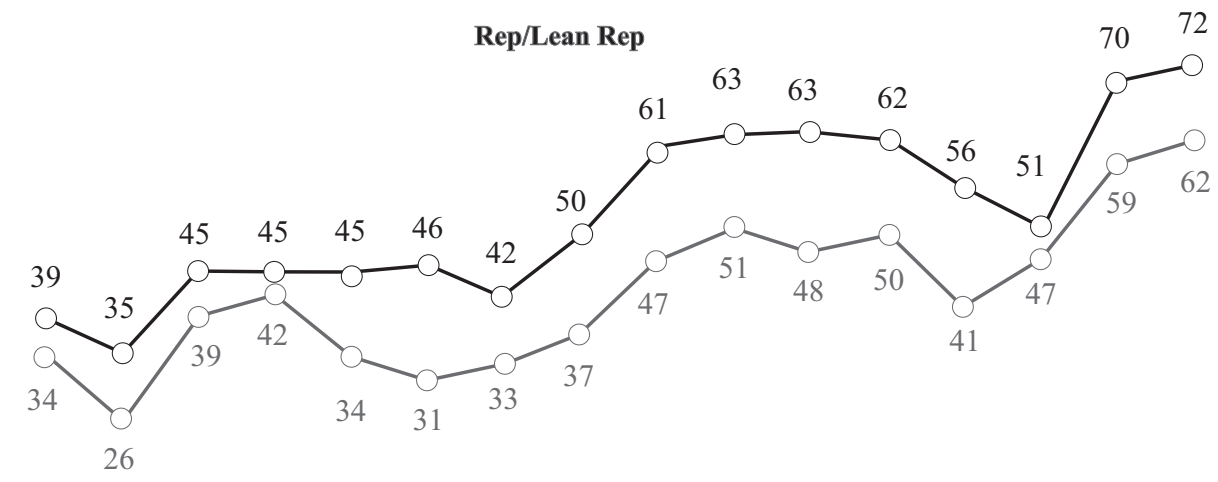

Dem/Lean Dem

0

$\begin{array}{lllll}2005 & 2008 & 2011 & 2014 & 2017\end{array}$

Source: Pew Research Center Survey Results (Devlin et al., 2020).

leader. Examining Figure 2 one cannot notice that strong and leaning supporters of the Democratic Party also increase their unfavorable opinion of China - from 41\% in 2017 to $62 \%$ as of March 2020 (Devlin et al., 2020). Another interesting finding of this survey is that the younger generations of respondents, who tend to be more positive about the views of foreign countries, are only several percentage points higher than the people of other ages in the negative opinion of China. For example, negative attitudes are shared by $53 \%$ of the age group $18-29,67 \%$ of the age group $30-49$, and $71 \%$ of the group 50 and older (Devlin et al., 2020).

There have been numerous US press publications about China and Russia during the coronavirus pandemic. Quantitative research is able to shed more light on the percentage of negative articles and determine significant factors (independent variables). A relatively short period of time of the pandemic might not provide researchers with large databases of the US periodicals testing theories and hypotheses. Qualitative research implies taking many cases, in this context, articles containing topics of the US views of Russia and China in the pandemic. There have been many stereotypes and conspiracy unscientific theories about the virus which do not need to be repeated in the academic paper. It is clear that the public frustrated with quarantine and dramatic changes to the life style attempt to find a scapegoat and source of all trouble. And the easiest strategy for the US newspapers is to feed this negative perception of China and use for political benefits.

The New York Times publication of 06 March 2020 used negative images of China - authoritarianism and secrecy which dramatically increased during the pandemic. The 
author if this article - Myers (2020) - provided evidence of journalist expulsion from China. The case of the Wall Street journal was accused of publishing a headline: "China is the Real Sick Man of Asia." The result was the expulsion of three journalists of this newspaper from China. The US was critical of the domestic view of China providing effective solutions and strategies and becoming the world leader in the fight against the coronavirus (Myers, 2020). The main point from the US approach to China is not to praise anything coming from China, even it might be the most effective strategy. Any positive comments about China or Russia are viewed as support for authoritarian structures and non-democratic ideology.

The author of the Washington Post article, Max Boot, emphasizes that the story of China's cause of the pandemic has been used by the Trump administration to cover its own misconceptions and bad guidance (Boot, 2020). The news in the early May of 2020 discussed the US considering punishments of China and the demand of reparations from Beijing. There were some discussions of cancelling some part of the US debt owned by China. China tried to cover up the epidemic at the beginning of the pandemic not providing enough information for other states and international organizations (Boot, 2020). This article also highlighted the cause of the virus. The Trump administration blamed China for creating it in a research facility in Wuhan (China). Senator Tom Cotton was cited in blaming the Communist leaders of China which "made a conscious decision to allow the virus to escape their borders" (Boot, 2020). Such descriptions of the article reflect the political motivated polemic and discussions about China. The information is accessed and used by political parties. Both the Washington Post and the New York Times present highly critical articles of the Republican Party and President Trump. Any Trump's statements and actions are immediately challenged. This can provide the explanation of the difference between Republicans and Democrats in their approach to China.

The Russian country image has been generally negative in the West in the recent years. The Russian internet publications display the digest of the western media approach to Russia. Such information was also repeated and reflected in the official Russian publications. The analysis of the aggressive approach of the world Media towards Russia was conducted between 28 September and 04 October, 2015 (Ria News, 2015). The content of the western publications was analyzed. The largest percentage of negative information in the national publications included the United Kingdom (49 negative articles out of 274), Poland (the second place, 26 out of 77). The United States had only 5 strongly negative publications, 126 moderately negative out of 223 . The study of just one week publications in the US showed that the Wall Street Journal works were mainly negative about Russia (28 out of 51), the Washington Post (19 out of 32), CBB (16 out of 33) (Ria News, 2015).

Several weeks later another review of the western media was conducted by the Ria Novosti (News). The analysis of the western publications provided some relative changes in the level of negativity towards Russia. The United Kingdom remained a leader of negative coverage (73 out of 161 publications), while other countries joined in this list (France, Ukraine, Spain, Czech Republic, Norway, Sweden, United Arab Emirates, Poland, Saudi Arabia). The main news stories focused on the case of Litvinenko, RussianBritish relations, and the crisis in the Russian economy in 2014-2016, Russian military action in Syria (Ria News, 2016). The United States did not get into the list of the top countries with the most unfavorable view of Russia. However, the percentage of nega- 
tive publications of the US media outlets dramatically increased. The Times magazine had 20 negative articles out of the total of 21.

Before the coronavirus pandemic, the Global Attitudes Survey to access the view of Russia was conducted in 33 countries (Huang, Cha, 2020). As stated in the Pew Research Center publication, the United States has one of the lowest ratings of Russia $(18 \%$, lower only in Sweden 12\%), while many more European states have more favorable opinions (for example, France and Poland - 33\%. Germany - 35\%). The negative perception of Russia dramatically increased in 2014 across the US and western European countries (Letterman, 2018; Huang, Cha, 2020). The Pew Research Center survey was conducted on May 14-August 12, 2018 (Letterman, 2018). More than a half of the US respondents $(52 \%)$ in this survey indicated that Russia plays a more important role in the world today compared to 10 years ago (Letterman, 2018). There is a difference in the approach to Russia dependent on generational views. Younger Americans tend to have more favorable views of Russia (27\% of the age 18-29 compared with $18 \%$ for the respondents 50 years and older) (Letterman, 2018).

Figure 3 presents the data of a survey of citizens for 2003-2019: American respondents rated Russia; Russian-USA. In the table positive moods to each other are clearly reflected - the arrival of new administration in the White House (B. Obama and D. Trump), the "reset" of Russian-American relations. After the annexation of Crimea to Russia, one can notice a sharp cooling in relations between the two countries. In 2019, positive perception was more than $18 \%$ (in turn, Russians perceive the United States more positively - 29\%) (Huang, Cha, 2020).

Figure 3. Russian-American Perceptions of each other. Pew Research Survey Results

Few in Russia, U.S. see ither country positively

$\%$ who have a favorable opinion of Russia/U.S.

$100 \%$

\section{Russian views of the U.S.}
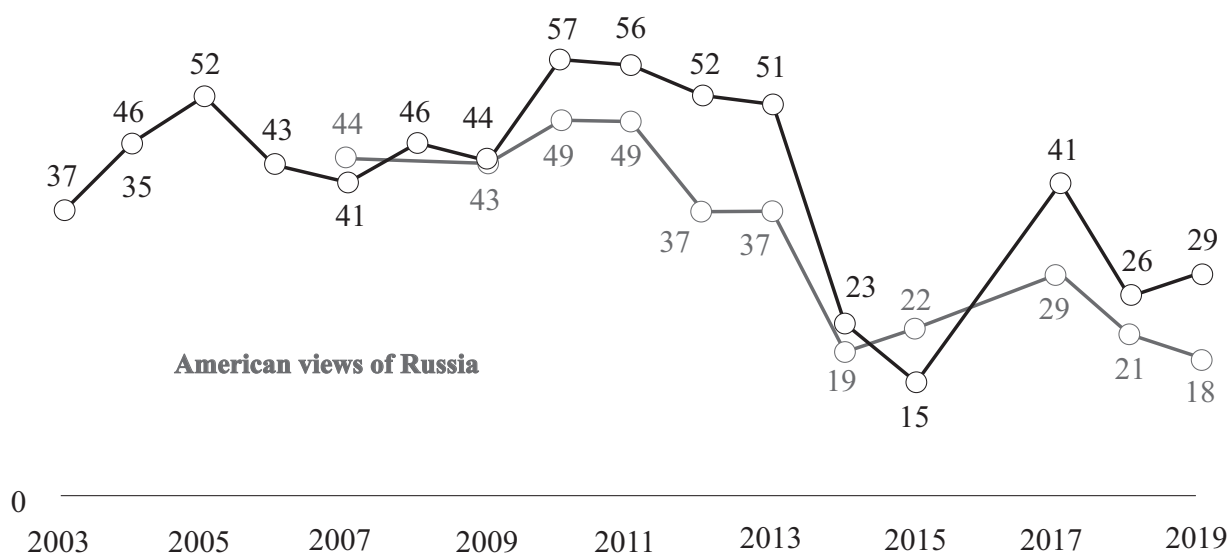

Source: Huang, Cha, 2020. 
There is an interesting observation from the Pew Research Survey of 2019 (Huang, Cha, 2020). Figure 4 shows that strong and Leaning Republicans tend to be better in their views of a Russian president Vladimir Putin. The gap along the partisan lines started widening in 2016 (Russian meddling in the US Presidential elections) and reaching the maximum difference in 21 percentage points in 2019. 31\% Republicans say that they have confidence in Russian President Vladimir Putin to do the right thing concerning world affairs compared with only $10 \%$ of Democrats.

\title{
Figure 4. The Republican/Democratic Views of Vladimir Putin
}

\author{
About a third of U.S. Republicans have confidence in Putin, \\ up significantly since 2015 \\ $\%$ who say they have confidence in Russian President Vladimir Putin to do the right \\ thing concerning world affairs \\ $100 \%$
}

\section{Republican/Lean Rep}

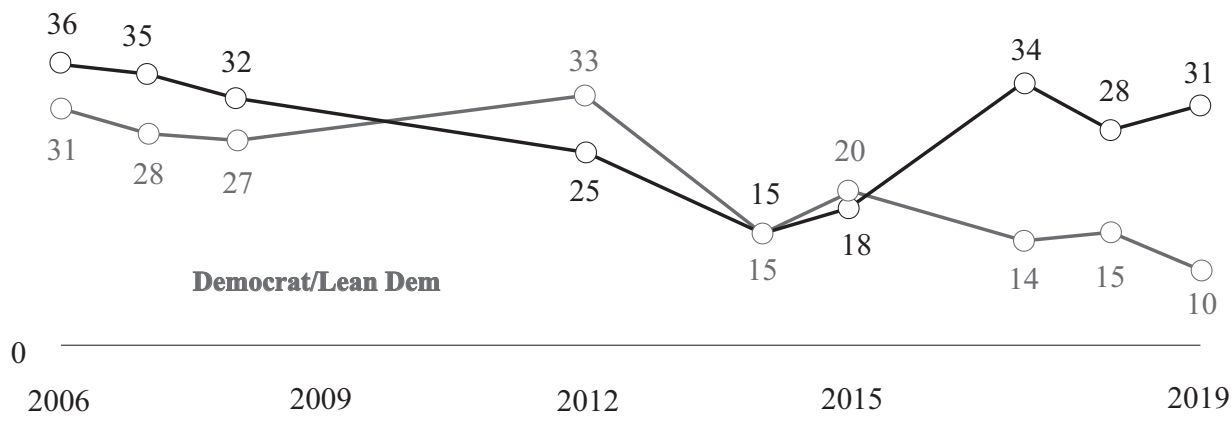

Another interesting finding of the article - the United States public generally has a negative look at both target countries - Russia and China. But the US population is divided along partisan lines. Preferences of Republicans and Democrats are totally opposite. While Democrats are more positive toward China, Republicans have a more positive look at Russia. It emphasizes the preferences of political parties and therefore the selection of information of respondents.

There is no doubt that this year will enter the history as the year filled with unprecedented shocks and unforeseen circumstances. Every day the news is full of surprises and even some shocks. The coronavirus pandemic has not caused many conflicts but aggravated and significantly affected many countries in the world. A coronavirus pandemic has drawn attention to the injustice and access to social welfare in the developed states. At the end of May 2020, the United States society, which is generally perceived as stable, law-abiding, experienced unforeseen and unprecedented violent protests. The worsening situations and escalations occur in many other parts of the world. The rally around the flag explanation might be revisited by scholars in the future. Leaders encountering 
diminishing public support in the domestic affairs can choose a military action abroad to divert the focus of the constituency.

In other words, a number of interactive methods can be employed in the analysis of the coronavirus pandemic. This is a new innovative method of Political Science research that relies heavily on the statistical significance of two variables working only in this pair. The rule of parsimony implies a minimum number of factors explaining most reality. Most of the research needs to choose one explanation or factor which can be difficult since previous research works have emphasized such importance. The choice for a Political Scientist is limited. There are basically four main factors that are used in the research works. The first set includes the economic explanation that follows works of Adam Smith and Karl Marx. Political explanations generally derive from the analysis of political institutions. Socio-demographic variables emphasize specific characteristics of a society. Lastly, a cultural approach is shared only by a small group of scholars, most famous ones are Samuel Huntington and Max Weber. It is difficult to get published stating one of these factors as the main explanation in the research work. A new approach relies on a combination of these factors, for example, a political variable (electoral systems) and a demographic variation (percentage of an ethnic minority group) would give a statistical significance to the main independent variable. Each of these variables would not work independently, Therefore, the coronavirus pandemic facilitates this new environment for the interaction of political groups intensifying long-term struggles and conflicts.

\section{Bibliography}

Boot M., Trump Can't Blame China for his Own Coronavirus failures, "The Washington Post", 04.05.2020, https://www.washingtonpost.com/opinions/2020/05/03/trump-cant-blame-chinahis-own-coronavirus-failures/, 22 May, 2020.

Devlin K., Silver L., Huang C. U. S., Views of China Increasingly Negative Amid Coronavirus Outbreak, "Pew Research Survey", 21.04/2020, https:/www.pewresearch.org/global/2020/04/21/u-sviews-of-china-increasingly-negative-amid-coronavirus-outbreak/, 14 May, 2020.

Downs A. (1957), An Economic Theory of Democracy, Harper Collins, New York.

Huang Ch., Cha J., Russia and Putin Receive Low Ratings Globally, "Pew Research Center", 07.02.2020, https://www.pewresearch.org/fact-tank/2020/02/07/russia-and-putin-receive-lowratings-globally/, 18 May, 2020.

Letterman C., Image of Putin, Russia Suffers Internationally, "Pew Research Center", 06 December 2018, https://www.pewresearch.org/global/2018/12/06/image-of-putin-russia-suffers-internationally/, 21 May, 2020.

Letters to the Editor Was China to blame for the pandemic? Depends on whom you ask, "The Washington Post", 10.05.2020, https://www.washingtonpost.com/opinions/was-china-to-blame-for-thepandemic-depends-on-whom-you-ask/2020/05/10/2d2a0c18-907b-11ea-9322-a29e75effc93_ story.html, 20 May, 2020.

Myers S., China Pushes Back as Coronavirus Crisis Damages its Image, "The New York Times", 04.03.2010, https://www.nytimes.com/2020/03/06/world/asia/china-coronavirus-image.html, 24 May, 2020.

Ria News (Novosti), 10.08.2015, https://ria.ru/20151008/1298362402.html, 15 May, 2020.

Ria News (Novosti), 28.01.2016, https://ria.ru/20160128/1366017819.html?in=t, 15 May 2020. 
Sniderman P., Brody R., Tetlock P. (1991), Reasoning and Choice: Explorations in Political Psychology, Cambridge University Press, Cambridge.

Zaller J. (1992), The Nature and Origins of Mass Opinion, Cambridge University Press.

\section{Wizerunek Chin i Rosji w prasie amerykańskiej podczas pandemii}

\section{Streszczenie}

Prasa amerykańska negatywnie przedstawia zarówno Rosję, jak i Chiny, a podczas obecnej pandemii wizerunek tych autorytarnych państw stał się jeszcze bardziej negatywny. Sytuacja dotycząca koronawirusa działa jako efekt interakcji, gdy bardziej radykalne postawy znajdują odzwierciedlenie $\mathrm{w}$ komunikatorach internetowych i mediach internetowych. Wcześniejsze tematy krytyki w mediach ustąpiły miejsca dominującemu tematowi - chińskiej odpowiedzialności za wirusy. Każda historia sukcesu pochodząca z Chin lub Rosji jest wątpliwa lub uciszana. Nie ma pozytywnych wiadomości w autorytarnym systemie politycznym. Do analizy treści wizerunku Rosji i Chin wykorzystano dane z New York Times.

Słowa kluczowe: wizerunek Chin, wizerunek Rosji, Pew Research Center, ankieta, opinia publiczna, stronniczość, Republikańska Partia Stanów Zjednoczonych, Partia Demokratyczna Stanów Zjednoczonych 